\title{
Koping Religius Remaja ODHA di Kota Bandung
}

\author{
Popy Siti Aisyah ${ }^{1 *}$, Anggriyana Tri Widianti ${ }^{1}$, Eli Lusiani ${ }^{2}$
}

\begin{abstract}
${ }^{1}$ Keperawatan Medikal Bedah, Prodi DIII Keperawatan, STIKes 'Aisyiyah, Bandung, Indonesia
${ }^{2}$ Keperawatan Anak, Prodi Profesi Ners Keperawatan, STIKes 'Aisyiyah, Bandung, Indonesia *Email Korespondensi: nursepops02@gmail.com
\end{abstract}

\section{ARTICLE INFO}

\section{HOW TO CITED:}

Aisyah, P.S., Widianti, A.T. \& Lusiani, E. (2020). Koping Religius Remaja ODHA di Kota Bandung. Jurnal Pendidikan Keperawatan Indonesia 6(1), p. 37-44

DOI:

10.17509/jpki.v6i1.21111

\section{ARTICLE HISTORY:}

\section{Received}

November 17, 2019

Revised

March 20, 2020

Accepted

April 23, 2020

Published

June 20, 2020

\section{ABSTRAK}

Remaja dengan HIV AIDS merupakan kelompok minoritas yang berkebutuhan khusus yang harus ditingkatkan kualitas hidupnya. Aspek spiritual sangat berperan penting dalam kehidupan remaja dimana bisa menjadi bagian perlindungan diri terhadap status kesehatan yang buruk. Keyakinan religius akan mempunyai peran penting dalam pengambilan keputusan yang besar dalam hidupnya. Tujuan penelitian ini untuk mengekplorasi koping religius remaja dengan HIV AIDS. Penelitian ini menggunakan pendekatan kualitatif fenomenologi dengan metode deskriptif eksploratif. Tehnik pengambilan sampling menggunakan purposeful sampling. Pengambilan data dilakukan terhadap 5 orang partisipan remaja ODHA dengan teknik semi-indepth interview. Pengolahan data menggunakan pendekatan Empirical Phenomenological Psychological untuk mendapatkan tema-tema yang sesuai dengan tujuan penelitian. Adapun tema-tema yang ditemukan dalam penelitian adalah penyakit yang dialami sebagai hukuman dari tuhan, koping religius pasif, religisiusitas yang rendah, self directing koping. Hal ini menunjukkan adanya kecenderungan remaja ODHA menggunakan pola koping religius negatif. Berdasarkan penelitian diatas diperlukan suatu upaya integrasi asuhan keperawatan dengan pendekatan spiritual pada remaja HIV khususnya kelompok LSL.

Kata kunci: remaja, HIV, spiritual, koping religius

\begin{abstract}
HIV infected adolescent are a minority group with special needs who must improve their quality of life. Spiritual aspect is important to adolescents, is usually considered a protective factor against a host of negative health outcomes. Religious faith have role in making major life decisions. The purpose of this study was to explore the religious coping of adolescents who are diagnosed with HIV AIDS. This research is a qualitative phenomenology design with decriptive explorative. The sampling technique used purposeful sampling. The data collection from five participants with semi in depth interviewed. Data analysis were used the empirical phenomenological Psychological method. The themes found in this study are illness was experienced as punishment from God, passive religious coping, low religiousity, self directing coping. This showed HIV infected adolescent with homosexual behaviour tended negative religious coping patterns. The result suggest that spiritual care is important for adolescent are diagnosed with HIV with homosexuality.
\end{abstract}

Keywords: adolescents, HIV, spiritual, coping religious. 


\section{PENDAHULUAN}

Masa remaja merupakan transisi masa anakanak menuju dewasa yang beranjak dari masa ketergantungan menuju kemandirian. Hal ini menunjukan rasa otonomi dan keinginan untuk membangun identitas diri mereka (Batubara, 2016). Pencarian jati diri inilah yang didasari oleh perubahan emosi, psikologis dan fisik.

Selain sebagai masa transisi, remaja sering dipandang memiliki masalah dalam proses pencarian jati diri mereka. Jika tidak diikuti dengan dukungan positif dari keluarga, lingkungan dan dukungan agama yang kuat, maka remaja dapat didominasi oleh dorongan seksual yang kuat (Verona, Murphy, \& Javdani, 2017). Hal ini disebabkan pada masa ini sedang terjadi perkembangan kematangan seksual. Berdasarkan itulah agama atau religiusitas menjadi faktor penting bagi remaja karena dalam religiusitas terdapat juga aturan perilaku seksual yang benar (Torralba \& Oviedo, 2009).

Perilaku seksual remaja saat ini yang berawal dengan pacaran, telah mengalami penyimpangan seksual. Hal ini disertai aktivitas seksual lain yang membuat melakukan hubungan seksual sebelum menikah (Brewster, Velez, Foster, Esposito, \& Robinson, 2016; Hartati, 2018). Perilaku seksual yang menyimpang ini menimbulkan risiko bagi remaja, salah satunya penyakit menular seksual hingga mengalami HIV/AIDS.

Munculnya HIV/AIDS di kalangan remaja menunjukan angka yang meningkat. Penemuan kasus HIV ibu dan anak daerah Jawa Barat sejak tahun 1987 sampai tahun 2016 berjumlah 18.727 jiwa. Jawa Barat menduduki peringkat ke-4 kasus HIV di Indonesia, setelah Jakarta, Jawa timur dan Papua. World Health Organization mengestimasi remaja usia 15-24 tahun sebanyak 10,3 juta menderita HIV/AIDS (Fatmala, 2016). Jumlah kasus HIV pada tahun 2017 dengan rentang usia 15-18 tahun berjumlah 240 orang, dengan cakupan wilayah Kabupaten Bandung, Bandung Barat, Kota Bandung dan Kota Cimahi (Kemenkes, 2018)

Menjalani hidup dengan HIV/AIDS menyebabkan stress psikologis yang berangsur dari waktu ke waktu dan masalah spiritual. Remaja dengan HIV/AIDS mengalami risiko depresi 2 kali dibanding penyakit lainnya. Munculnya depresi ini disebabkan karena munculnya efek fisik dari HIV dan obat HIV, perasaan malu perasaan bersalah, berduka, penyakit yang tidak dapat disembuhkan, adanya stigma hingga dampak HIV kekematian. Ketika remaja tidak mampu mengelola spiritual dengan baik, maka akan menambah beban dalam permasalah psikologis mereka dengan HIV nya.

Perkembangan spiritual remaja mempengaruhi cara pandang dan sikap remaja dalam menghadapi masalah. Perkembangan spiritual yang positif akan mengarahkan remaja dalam membentuk nilai atau sikap yang baik. Apabila perkembangan spiritual negatif akan memicu koping spiritual yang negatif sehingga berdampak terhadap cara pandanganya dalam menghadapi permasalahan, krisis dalam hidup serta penurunan kualitas hidup (Cotton, Zebracki, Rosenthal, Tsevat, \& Drotar, 2006; Lin, Saffari, Koenig, \& Pakpour, 2018; Stecz \& Kocur, 2014). Hal tersebut diatas menunjukkan bahwa pemenuhan kebutuhan spiritual serta upaya peningkatan koping religius mempunyai manfaat dalam pengelolaan remaja yang terinfeksi HIV.

Meningkatnya spiritualitas remaja dengan HIV memprediksi perkembangan penyakit HIV yang lebih lambat, menurunkan tekanan psikologi, dan peningkatan fungsi sosial. Hal tersebut akan dirasakan oleh remaja dengan pengelolaan koping religius yang positif. Sedangkan remaja dengan pengelolaan koping religius negatif memunculkan sikap penolakan terhadap terapi antiretroviral, perasaan mendalam hukuman dari Tuhan dan penyimpangan jati diri remaja(Agustin, 2018; Lyon et al., 2014; Tanjung, 2016). Hal ini yang mendasari diperlukan lebih banyak mengenai eksplorasi koping religius kelompok remaja dengan HIV/AIDS dalam proses penerimaan diagnosisnya.

Berdasarkan uraian diatas, bagaimanakah pola koping religius yang dimiliki oleh remaja dengan HIV/AIDS di Rumah Cemara Bandung? Penelitian ini bertujuan mengeksplorasi mengenai pola koping religius remaja yang mengalami HIV/AIDS di kota Bandung. 


\section{METODE \\ Desain Penelitian}

Penelitian ini termasuk kedalam penelitian kualitatif. Adapun pola penelitian yang digunakan adalah pola deskriptif yaitu meneliti objek dengan melukiskan keadaan atau persoalan yang dengan cara menafsirkan data untuk menarik dan mengambil simpulan secara umum (Lexy, 2012) Peneliti meggunakan deskriptif eksploratif yaitu mendeskripsikan strategi koping religius remaja dengan HIV/AIDS secara mendalam di kota Bandung.

\section{Partisipan penelitian}

Subjek penelitian ini adalah remaja lakilaki/perempuan, berjumlah 5 orang. Teknik pengambilan sample ditentukan dengan purposeful sampling. Prinsip dasar besar sampling dalam penelitian kualitatif adalah saturasi data, dimana tidak ada informasi data baru dari pengalaman yang diambil. Partisipan adalah kelompok tertutup hanya diketahui oleh konselor pendamping HIV. Dalam proses penelitian, peneliti tetap memperhatikan aspek kerahasiaan, otonomi (tidak ada paksaan), serta menjunjung tinggi nilai beneficence dan nonmaleficence. Oleh karena itu proses pemilihan partisipan melibatkan konselor pendamping HIV dari KPA kota Bandung. Pada penelitian peneliti menggunakan 5 partisipan karena dari kelima partisipan peneliti tidak menemukan informasi baru. Adapun kriteria inklusi yang ditetapkan dalam penelitian meliputi partisipan terdiagnosa HIV, usia remaja akhir (18-23 tahun), bersedia menjadi responden, mampu berkomunikasi dengan partisipan secara terbuka. Kriteria ekslusi yang ditetapkan penelitian ini adalah partisipan dalam kondisi tidak memungkinkan dilakukan wawancara seperti gangguan bicara.

\section{Teknik pengumpulan data}

Pengumpulan data dilakukan di kota Bandung bekerjasama dengan Yayasan Rumah Cemara Bandung dan KPA kota Bandung. Pelaksanaan penelitian dilakukan bulan Mei - Juni 2019. Teknik pengumpulan data dilakukan dengan cara wawancara mendalam semi terstruktur (semi indepth interview) bertujuan untuk mengeksplorasi strategi koping religius remaja dengan HIV/AIDS secara mendalam.. Peneliti menggunakan pedoman wawancara yang telah dibuat sebelumnya, namun pada saat proses wawancara pertanyaan tetap terbuka, tidak kaku dan dikembangkan oleh pewawancara dengan mengikuti respon partisipan. Salah satu pertanyaan yang ditanyakan oleh peneliti "Ceritakan bagaimana cara saudara mengatasi hal-hal yang membuat saudara cemas atau khawatir?". Hasil wawancara direkam dengan alat perekam (recorder) dan peneliti juga mengobservasi respon non verbal partisipan dan semua kejadian penting selama wawancara untuk kemudian disusun menjadi catatan lapangan dengan menggunakan catatan lapangan (field notes) untuk menggambarkan kejadian yang ditemukan peneliti dan partisipan selama proses wawancara seperti apa yang didengar, dialami, dan dipikirkan oleh peneliti dalam merefleksikan data yang didapat (Afiyanti, Y . Rachmawati, 2014).

Proses pengumpulan data diawali dengan proses perizinan ke Yayasan Rumah Cemara. Peneliti dibantu oleh konselor pendamping dari Komisi Penangananan AIDS di kota Bandung untuk mencari partisipan yang sesuai dengan kriteria inklusi yang ditetapkan oleh peneliti. Peneliti memastikan ulang secara langsung bahwa partisipan yang ditunjuk oleh konselor pendamping sudah sesuai dengan kriteria yang ditetapkan. Setelah dilakukan pemilihan partisipan dilanjukan proses pendekatan bina saling percaya dan informed consent pada partisipan. Petugas yang melakukan pengambilan data terdiri dari tiga orang. Ketua peneliti berperan sebagai pewawancara, anggota peneliti sebagai penulis catatan lapangan saat wawancara berlansung, dan anggota peneliti ketiga berperan sebagai observer yang melakukan observasi non verbal partisipan dari jarak 2-3 meter (Afiyanti, Y. Rachmawati, 2014).

Peneliti memberikan kesempatan pada partisipan untuk menentukan tempat dan lokasi wawancara. Partisipan menyepakati proses wawancara di sebuah cafe. Durasi waktu wawancara mendalam antar setiap partisipan bervariasi dari 60 sampai 90 menit. Hal ini dikarenakan karakteristik partisipan yang bervariasi, partisipan 2,4,5 menghabiskan waktu 90 menit karena karakternya yang supel dan 
senang bercerita. Sedangkan partisipan 1 dan 3 karakternya cenderung pendiam sehingga 60 menit untuk melakukan proses wawancara. Wawancara dilakukan hanya satu kali karena peneliti dirasakan sudah mendapatkan data mendalam. Proses wawancara terekam di IC recorder sony tipe ICDUX512 dan selanjutnya seluruh rekaman dibuat transkrip wawancara.

\section{Analisis Data}

Analisis data menggunakan pendekatan Empirical Phenomenological Psychological (EPP) dengan urutan sebagai berikut: 1) peneliti membaca transkrip data 2-3 kali sampai $r$ memahami. 2) peneliti megidentifikasi meaning unit(MU) atau membedakan menjadi unit unit kecil. 3) Menransformasikan MU oleh peneliti dari bahasa subjek kepada bahasa peneliti 4) melakukan sintesa rangkuman MU menjadi struktur yang tersituasikan, 5) peneliti mengubah struktur yang tersituasikan menjadi struktur tema yang lebih umum (Lexy, 2012).

\section{Keabsahan data}

Keabsahan uji data dilakukan dengan proses kredibilitas, dependability, dan confirmability dan transferability. Proses kredibilitas dilakukan peneliti dengan cara memverifikasi tema-tema yang diambil kepada partisipan. Apakah makna yang diambil peneliti sesuai dengan persepsi partisipan. Depentability dilakukan dengan memperhatikan data yang sama luasnya untuk seluruh partisipan. Confirmaability dilakukan dengan cara mengevaluasi keputusan pada narasumber peneliti kualitatif yaitu dosen keperawatan di luar anggota peneliti. Transferability dilakukan dengan eksternal check tema yang telah dipilih kepada remaja ODHA lain yang sama kriteria inklusi penelitian namun tidak diambil dalam pengumpulan data. Remaja yang dijadikan sebagai perwakilan adalah 2 remaja ODHA di wilayah kota Bandung (Afiyanti, Y . Rachmawati, 2014).

\section{Etik Penelitian}

Peneliti telah melakukan persyaratan uji etik penelitian kesehatan pada Komisi Etik Penelitian Kesehatan Di STIkes Aisyiyah Bandung dengan
Nomor 17/KEP.02/STIKes-AB/V/2019. Semua partisipan memiliki peluang untuk dipilih dan berkontribusi dalam penelitian tanpa diskriminasi. Informed consent diberikan pada partisipan setelah memperoleh berbagai informasi berupa tujuan penelitian, prosedur penelitian, durasi keterlibatan partisipan, hak-hak partisipan dan bentuk partisipannya dalam penelitian yang dilakukan dari peneliti. Partisipannya wajib memperoleh informasi yang sejelas- jelasnya mengenai tujuan, manfaat, metode sumber, pembiayaan, keuntungan dan potensi resiko akibat yang mungkin timbul dari proses penelitian, upaya meminimalkan hak tidak berpartisipasi dalam penelitian atau mengundurkan diri tanpa adanya tekanan.

\section{HASIL}

\section{Gambaran karakteristik informan}

Penelitian ini merupakan studi kualitatif terhadap 5 orang remaja ODHA yang berdomisili di kota Bandung. Wawancara mendalam semi terstruktur dilakukan selama 2 kali pertemuan untuk masing-masing partisipan. Adapun gambaran karakteristik informan penelitian berada pada rentang usia 20-23 tahun, sebagian besar berlatar belakang pendidikan SMA kecuali partisipan ke-1(P1), serta sebagian besar beragama Islam kecuali partisipan ke- 4(P4) beragama katolik. Lama terdiagnosa HIV pada partisipan berada pada rentang waktu 0-3 tahun dengan sebagian besar partisipan remaja terinfeksi HIV karena perilaku beresiko laki seks sesama laki kecuali pada partisipan yang ke-2 (P2).

\section{Strategi Koping Religius Remaja Odha}

Berdasarkan hasil wawancara kecenderungan pola koping religius yang digunakan adalah koping negatif selama menjadi ODHA, adapun beberapa analisa tema yang dihasilkan dalam penelitian ini diantaranya:

1. Penyakit yang dialami sebagai bentuk hukuman dari tuhan.

Ungkapan yang muncul pada informan diantaranya:

"terjadi ini karena, tahu dari dosa" (p1.w1) "penyakitnya kutukan tuhan imagenya" (P2.w1) 
"kenapa harus sama saya, cuman sy instriospeksi diri juga sih, karena perilaku saya juga" (P5.w1)

2. Koping religius pasif;

Adapun ungkapan yang didapatkan dari beberapa informan sebagai berikut:

"Setiap kali dari temen gak ngaruh, dari temen gak ngaruh, baru minta tolong sama allah" (p1.w1)

"tuhan gak pernah tidur mereka kirim ortu" kalo solat sering bolong," (p2.w1)

"lebih mendekatkan diri aja, Cuma saya ga sampai kesitu" (p3,w1)

"posisi butuh dia tapi dia (tuhan) tidak ada, saya ke gereja atau saya minum-minum di rumah sendirian, putar-putar lagu" (P4.w2) "pasrah aja, sekuatnya gimana" (p5.w2)

3. Religiusitas rendah

Dari ke empat informan LSL memiliki kecederungan aktivitas ibadah yang tidak sesuai dengan yang diharuskan. Adapun ungkapan yang muncul diantaranya:

"saya hanya shalat shubuh saja" (p2 "kalo shalat sering bolong" (p2.w2)

"shalat masih dilakukan tapi jarang, shalat magrib aja"(P5.w1)

"ke gereja kadang seminggu sekali, kadang seminggu 2 kali, tergantung mood" (P4w2).

4. Self directing coping

Mereka cenderung menggunakan kekuatan mereka sendiri atau sumber daya yang ada di lingkungan tanpa ada pelibatan unsur Tuhan. Adapun ungkapan informan yang muncul diantaranya:

"Musik atau nyibukin diri gak mau ada yang ganggu" (p1w1)

"komunitas sesama HIV deket selalu support saya, Kalo ada apa apa orang tua pasang badan" (P2.w2)

"saya ke gereja atau saya minum-minum di rumah sendirian, putar-putar lagu" (P4.W1) "Kalo ada masalah berat baru kembali kalo lagi senang lupa" (P5.W2)

\section{PEMBAHASAN}

Partisipan remaja pengidap HIV AIDS/Orang Dengan HIV/AIDS (ODHA) merupakan kelompok usia remaja akhir. Remaja akhir merupakan usia yang memilki identitas yang lebih kuat, mulai memikirkan masa depan, konsisten terhadap minat serta mempunyai ide ide yang bermakna untuk pemenuhan perannya (Batubara, 2016). Tingkat pendidikan partisipan hampir semuanya berpendidikan menengah, namun kemampuan koping seseorang tidak berhubungan dengan tingkat pendidikannya (Xu, 2016).

Remaja yang terinfeksi positif akan mudah mengalami distress spiritual sehingga memberikan respon yang negatif terhadap Tuhan atas apa yang terjadi pada dirinya. Hal ini serupa dengan penelitian sebelumnya bahwa remaja yang terinfeksi penyakit HIV lebih meyakini bahwa ia sedang menjalani hukuman Tuhan.(Lyon et al., 2014). Setiap stresor atau situasi yang terjadi sebagai bentuk hukuman dari Tuhan merupakan respon pola koping religious negatif (Xu, 2016).

Munculnya persepsi sebagai hukuman dari Tuhan dikarenakan partisipan mendapatkan penularan HIV dari perilaku yang diyakini tidak sejalan dengan aturan dan norma agama. Partisipan hampir sebagian dari kelompok populasi beresiko: komunitas minoritas Lelaki seks sama Laki (LSL) sebanyak 4 orang dan satu orang merupakan mantan pengguna narkoba jarum suntik sejak 2 tahun lalu bukan LSL. Adanya stigmatisasi diri bahwa ODHA adalah kelompok yang tidak disukai oleh masyarakat karena dianggap bersumber dari perilaku yang tidak baik membuat ODHA memiliki kecenderungan menyembunyikan identitas diri (Mariany, Asfriyati, \& Sanusi, 2019). Gay merupakan kelompok minoritas yang dianggap sebagai kelompok yang berperilaku melanggar aturan agama.

Koping religius pasif adalah seseorang bergantung kepada Tuhan dan menunggu bantuan Tuhan dalam menghadapi persoalan hidup, tetapi tidak ada upaya meningkatkan aktivitas mendekatkan diri Tuhan (Xu, 2016). Berdasarkan hasil penelitian pada dasarnya informan meyakini bahwa adanya Tuhan tetapi tidak ada upaya untuk mengunakan koping yang konstruktif melalui agama. Dukungan sosial yang didapatkan oleh informan merupakan bagian dari pertolongan Tuhan sehingga tidak ada upaya dari diri sendiri untuk menjadi seseorang yang lebih religius. Hal ini menunjukkan bahwa aspek spiritualitas yang 
dikembangkan terbatas pada domain proksimal spiritual yaitu keyakinan akan adanya sang pencipta yang mengatur kehidupan namun tidak mengembangkan aspek kegiatan religius yang meningkatkan spiritual.

Aspek proksimal adalah suatu upaya pemaknaan sumber spiritual individu, sementara aspek distal spiritual adalah pemaknaan spiritualitas melalui perilaku atau tindakan (Cotton, Zebracki, Rosenthal, Tsevat, \& Drotar, 2006; Trevino et al., 2010). Hal ini sejalan dengan ungkapan informa tidak yang melaksanakan aktivitas ibadah secara rutin. Tema ini akan dibahas pada tema selanjutnya yang berkaitan dengan religiusitas rendah.

Religiusitas adalah suatu tindakan formal seseorang yang berkaitan dengan aktivitas beragamanya sebagai bentuk komitmen diri terhadap agama nya yang diekspresikan (Trevino et al., 2010). Aspek religisiutas terdiri dari dari aspek keyakinan, peribadatan, penghayatan keagamaan, pemahaman pengetahuan agama serta aspek etika (Komarudin, 2018).

Hasil penelitian menunjukkan bahwa aspek religisiutas dalam hal praktik ibadat dan penghayatan terhadap beragama serta intelektual pengetahuan ajaran agama yang diemban masih rendah. Penghayatan terhadap beragama dan pengetahuan terhadap agama masih rendah ditunjukkan dengan ungkapan informan ke-1, informan ke-2, dan informan ke-4 Adapun ungkapan yang muncul diantaranya

"Penting sih, tapi ngejalaninnya gak terlalu penting jadi hanya sebagai identitas saja" (p1.w1)

"konselor Irfan bukan muslim tapi mereka suka ngasih kekuatan" ( $p 2 . w 1)$

"mau sholat atau gak terserah kita yang penting kita banyak berbuat baik ke orang" (p2.w2)

"kalo dulu dulu aku yang namanya quran sampai hatam 3 kali, aku ngaji lancar, baca quran sampai ga ada bolongnya" (p5.w2) "seksual ga bisa di kaitkan dengan agama karena ga ada kaitannya, udah beda jalur istilahnya" (p4.w1)

Berdasarkan tiga ungkapan diatas menunjukkan bahwa remaja ODHA LSL memiliki pola koping religious negatif yang mengungkapan perasaan ketidakpuasan terhadap hal-hal yang berkaitan dengan nilai-nilai keagamaan atau dinamakan atau suatu pola koping religius negatif yang dinamakan interpersonal religious discontent (Xu, 2016). Ungkapan ketidakpuasan muncul karena keterbatasan dalam pemahaman dan penghayatan dalam beragama. Hampir seluruh informan mengetahui bahwa tidak beribadah merupakan perbuatan yang tidak sejalan dengan agama, tetapi belum menemukan makna beragama. Aktivitas beragama hanya terbatas pelaksanaan aktivitas ibadah rutin semata atau sekedar berbuat baik pada sesama. Penyimpangan orientasi seksual yang dialami oleh keempat informan diakui sebagai perbuatan yang dilarang dalam ajaran agama yang mereka anut. Informan ke-1, ke-4, dan ke-5 mengungkapkkan bahwa agama yang mereka anut melarang tetapi mereka kesulitan untuk menghilangkan kebiasaan tersebut tetapi mereka kesulitan untuk berubah.

Kondisi demikian berdasarkan tingkatan spiritual dalam perspektif Islam adalah berada pada tahap Nafs lawwamah (The regretful self). Tingkat spiritualitas nafs lawwamah adalah dimana seorang individu memiliki kesadaran terhadap membedakan perilaku yang benar maupun yang salah namun belum mampu kemampuan untuk berubah ke arah yang lebih baik meskipun sudah timbul perasaan menyesal (Jumala, 2017). Usia remaja merupakan tahap perkembangan yang paling dipengaruhi oleh teman sebaya. Hal ini sejalan dengan ungkapan informan ke-1, maupun informan ke-5 merasa sulit beranjak dari lingkungan sesama gay. Informan ke-1 mengungkapkan "aku juga terbawa karna mereka (temen) gak terlalu itu ke agama" (P1.w1).

"godaan lebih berat buat di lawan, jadi ya itu susah banget aku" (P5.w1).

Semakin lama seseorang berada pada kondisi spiritual nafs lawwamah semakin lama seseorang tersebut mendapatkan godaan yang menyulitkan terjadi peningkatan spiritual (Jumala, 2017).

Kondisi lain ditemukan pada informan ke- 2 dan ke-3 yang mendapatkan dukungan positif dari lingkungan keluarga cenderung memiliki tingkatan spiritual pada Nafs mulhimma (The inspired self). Informan ke-2 pada saat wawancara mengungkapkan 
bahwa saat ini sudah tidak mempunyai hubungan sesama jenis. Hal serupa terjadi pada informan ke-3 mengungkapkan bahwa saat ini lebih dekat dengan keluarga, sudah tidak mempunyai kebiasaan nakal seperti satu tahun lalu dan ingin banyak mempelajari agama. Kondisi tingkatan spiritual seseorang dengan Nafs mulhimma menunjukkan perilaku kepada arah yang lebih baik bahkan nuraninya terus mendorong untuk memperkuat usahanya walaupun terkadang usahanya belum maksimal dilakukan (Jumala, 2017).

Hal ini menunjukkan bahwa seorang remaja ODHA dalam pemenuhan kebutuhan spiritualnya tidak bisa sendiri membutuhkan dukungan dari keluarga atau orang yang paling membuatnya berharga. Dukungan sosial berupa keluarga yang kondusif akan membantu mengarahkan remaja dalam mencapai kematangan beragama. Kematangan beragama yang baik pada usia remaja akan membantu seorang remaja dalam membangun strategi koping yang positif (Hartati, 2018; Indirawati, 2006). Apabila dukungan sosial tidak berfungsi secara baik maka kecenderungan remaja menggunakan koping religious negatif semakin besar.

Hasil penelitian menunjukkan bahwa seluruh informan memiliki kecenderungan menggunakan tehnik penyelesaian masalah dengan melibatkan Tuhan disaat semua cara penyelesaian masalah tidak membantu. Ketika seseorang mencari kontrol melalui inisiatif dirinya dengan meminta bantuan orang lain terlebih dahulu atau mencari cara lain. Tindakan seperti itu merupakan bentuk koping religious negatif dimana jalan melalui pertolongan agama dijadikan sebagai jalan terakhir bukan jalan utama.(Usselman, 2017). Hal ini menunjukkan kecenderungan pola koping yang negatif pada remaja.

Walaupun partisipan mempunyai kecenderungan penggunaan koping religius negatif, pada dasarnya mereka mempunyai potensi untuk menggunakan koping positif. Hal ini ditunjukkan dengan adanya keinginan harapan positif atas kejadian yang dialami. Hasil wawancara dari seluruh partisipan menunjukkan bahwa hampir mempunyai ingin menjalani kehidupan keinginan yang lebih baik dalam aspek spiritual. Adapun ungkapan informan yang muncul diantaranya:
"Pengennya sih lebih sholeh" (P1.w2); "Istilahnya Allah ngasih kesempatan ke dua, kita harus ambil dan jangan sia-siakan" (p1.w2); "Takutnya meninggal esok, kadang berproses yang namanya istiqomah banget masih belum, tapi memproses untuk lebih baik." (p3.w2); "ingin menikah agar bisa membahagiakan mamah" (P5.w2).

Berdasarkan ungkapan diatas menunjukkan bahwa informan remaja pada dasarnya ingin memilki kehidupan yang lebih sejahtera secara spiritual selama menjalani penyakit HIV. Harapan yang lebih baik selama menjalani perannya sebagai ODHA sangat diharapkan (Collein, 2010; Lyon et al., 2014). Hal ini menunjukkan bahwa ada keinginan dari informan untuk meningkatkan spiritualitas mereka walaupun masih abstrak dalam langkah-langkah yang akan diambil. Keadaan jiwa seperti ini menunjukkan bahwa harus ada yang membantu dalam melawan ego dirinya sendiri untuk senantiasa mematuhi ajaran agama dan benar-benar istiqamah melaksanakannnya. Kekalahan pada tahap ini menyebabkan mereka hilang ketakwaannya kepada Allah yang akan membawa pada kondisi distress spiritual. Integrasi pendekatan spiritual dalam asuhan keperawatan pada kelompok remaja ODHA akan membantu remaja mempunyai kesejahteraan spiritual yang baik(Lyon et al., 2014; Sanagouye Moharer, Raisi, \& Sultan Ahmadi Moghaddam, 2018).

\section{SIMPULAN}

Strategi koping remaja ODHA yang digunakan memiliki kecederungan perilaku koping religius negatif. Tema yang didapatkan dalam penelitian diantaranya penyakit yang dialami sebagai hukuman dari tuhan, koping religius pasif, religisiusitas yang rendah, self directing koping. Kecenderungan koping religius negatif akan sangat beresiko terhadap kejadian distress spiritual yang dapat memicu tingginya resiko bunuh diri pada kalangan ODHA. Oleh karena itu Peningkatan spiritualitas di kalangan remaja khususnya kelompok ODHA sangat penting sebagai salah satu upaya peningkatan kualitas hidup ODHA. Penelitian selanjutnya dapat diidentifikasi bagaimana kebutuhan spiritual pada pasien remaja HIV LSL sebagai upaya dalam meningkatkan kualitas hidup remaja ODHA yang LSL. 


\section{DAFTAR PUSTAKA}

Afiyanti, Y . Rachmawati, I. (2014). metodologi penelitian kualitatif dalam riset keperawatan. Depok: Raja Grafindo Persada.

Agustin, I. S. (2018). Hubungan Strategi Koping Religius dengan Penyesuaian Diri pada Pasien HIV / AIDS di RSUD Gunungsitoli.

Batubara, J. (2016). Adolescent Development (Perkembangan Remaja). Sari Pediatri, 21. https://doi.org/10.14238/sp12.1.2010.21-9

Brewster, M. E., Velez, B. L., Foster, A., Esposito, J., \& Robinson, M. A. (2016). Minority stress and the moderating role of religious coping among religious and spiritual sexual minority individuals. Journal of Counseling Psychology, 63(1), 119-126. https://doi.org/ $10.1037 /$ cou0000121

Collein, I. (2010). Makna Spiritualitas Pada Pasien HIV/AIDS Dalam Konteks Asuhan Keperawatan Di RSUPN dr. Cipto Mangunkusumo Jakarta. Fik Ui, 3.

Cotton, S., Zebracki, K., Rosenthal, S. L., Tsevat, J., \& Drotar, D. (2006). Religion/spirituality and adolescent health outcomes: A review. Journal of Adolescent Health, 38(4), 472480. https://doi.org/10.1016/j.jadohealth. 2005.10.005

Fatmala, R. D. (2016). Dalam Pemanfaatan Vct Oleh Laki-Laki Seks. Jurnal Berkala Epidemiologi, (1), 138-150. https://doi.org/ 10.20473/jbe.v4i1.138-150

Hartati, S. (2018). Tazkiyatun Nafs as an Effort to Reduce Premarital Sexual Behavior of Adolescents. Islamic Guidance and Counseling Journal, 1(1), 33. https://doi.org/ 10.25217/igcj.v1i1.207

Jumala, N. (2017). Memahami Tingkatan Spiritual Manusia Dalam Mendeteksi Krisis Nilai Moral Understanding the Human Spiritual Rank In Detecting Moral Crisis Values. JPPUMA: Jurnal Ilmu Pemerintahan Dan Sosial Politik, 5(1), 42-50.

Kemenkes. (2018). General situation of HIV/AIDS and HIV test (p. 12). p. 12.

Lexy, M. (2012). metodologi penelitian kualitatit. bandung: Remaja Rosdakarya.

Lin, C. Y., Saffari, M., Koenig, H. G., \& Pakpour, A. H. (2018). Effects of religiosity and religious coping on medication adherence and quality of life among people with epilepsy. Epilepsy and Behavior, 78, 45-51. https://doi.org/10.1016/j.yebeh.2017.10.008
Lyon, M. E., Garvie, P., He, J., Malow, R., McCarter, R., \& D'Angelo, L. J. (2014). Spiritual Well-Being Among HIV-Infected Adolescents and Their Families. Journal of Religion and Health, 53(3), 637-653. https://doi.org/10.1007/s10943-012-9657-y

Mariany, B. S., Asfriyati, \& Sanusi, S. R. (2019). Stigma, depresi, dan kualitas hidup penderita HIV: studi pada komunitas "lelaki seks dengan lelaki" di Pematangsiantar. 35(4), 139-146.

Sanagouye Moharer, G., Raisi, M., \& Sultan Ahmadi Moghaddam, F. (2018). Relationship between Religious Coping Styles and Quality of Life in HIV-Positive Patients. Journal of Religion and Health, 5(2), 58-67.

Stecz, P., \& Kocur, J. (2014). Religiousness, Religious Coping with Illness, and Psychological Function Among Polish Elderly Patients with Osteoarthritis Undergoing Arthroplasty. Journal of Religion and Health, 54(2), 554-570. https://doi.org/ 10.1007/s10943-014-9842-2

Tanjung, D. M. (2016). Karakteristik Distress Spiritual pada OrangDengan HIV/AIDS (ODHA) di RSUP Haji Adam Malik Medan. Retrieved from http://repository.usu.ac.id/ handle/123456789/63305

Torralba, J., \& Oviedo, L. (2009). Religious coping in adolescents: New evidence and theological relevance Josefa Torralba and Lluis Oviedo. (1997), 1-15.

Usselman, C. W. N. S. S. J. R. B. (2017). Positive and Negative Religious/Spiritual Coping and Combat Exposure as Predictors of Posttraumatic Stress and Perceived Growth in Iraq and Afghanistan Veterans. Physiology \& Behavior, 176(3), 139-148. https://doi.org/ 10.1016/j.physbeh.2017.03.040

Verona, E., Murphy, B., \& Javdani, S. (2017). Gendered Pathways: Violent Childhood Maltreatment, Sex Exchange, and Drug Use. Physiology \& Behavior, 176(5), 139-148. https://doi.org/10.1037/a0039126.

Xu, J. (2016). Pargament's Theory of Religious Coping: Implications for Spiritually Sensitive Social Work Practice. British Journal of Social Work, 46(5), 1394-1410. https:// doi.org/10.1093/bjsw/bcv080. 